Research Article

\title{
Nanoscale Synthesis of Metal(II) Theophylline Complexes and Assessment of Their Biological Activity
}

\author{
Ahmad Hussein Ismail ${ }^{1 \llbracket}$, Hassanain Kamil Al-Bairmani ${ }^{1}$, Zainab Sabri Abbas ${ }^{1}$, \\ Ahmed Mahdi Rheima ${ }^{2}$ \\ ${ }^{1}$ Mustansiriyah University, College of Science, Department of Chemistry. Baghdad, Iraq. \\ ${ }^{2}$ Wasit University, College of Science, Department of Chemistry, Kut, Iraq. \\ — Corresponding authors. E-mail: ah2042013@uomustansiriyah.edu.iq; arahema@uowasit.edu.iq
}

Received: Feb. 4, 2020; Accepted: Apr. 13, 2020; Published: Apr. 16, 2020

Citation: Ahmad Hussein Ismail, Hassanain Kamil Al-Bairmani, Zainab Sabri Abbas, and Ahmed Mahdi Rheima, Nanoscale Synthesis of Metal(II) Theophylline Complexes and Assessment of Their Biological Activity. Nano Biomed. Eng., 2020, I2(2): I39-I47.

DOI: 10.5101/nbe.v12i2.p139-147.

\begin{abstract}
Three nanocomplexes of $\mathrm{Cu}(\mathrm{II})$, Co(II), and $\mathrm{Ni}(\mathrm{II})$ with theophylline were synthesized by ultrasonic sonication method. This method was used to produce smaller and narrow-distributed nanoparticles without any aggregations. Melting point, molar conductivity, solubility, flame atomic absorption, Fourier-transform infrared spectroscopy (FTIR) and elemental analysis (C, H, N, and S) were used to identify and to suggest the structure of the synthesized nanocomplexes. The transmission electron microscopy (TEM) results exhibited that the size of nanocomplexes was in the range of $15-25 \mathrm{~nm}$. The efficacy of the synthesized nanocomplexes was examined against four types of bacterial strains, Staphylococcus aureus, Bacillus subtilis (gram-positive bacteria), and Klebsiella pneumoniae, Escherichia Coli (gram-negative bacteria). The results showed that all nanocomplexes had very high susceptibility to inhibit bacterial growth, as they resulted in an inhibition zone between $98 \%$ and $100 \%$. The copper nanocomplex gave the highest inhibition zone by $100 \%$ for each type of bacterial strains, due to the surface plasmon. Therefore, a further test for the copper nanocomplex $\mathrm{Cu}(\mathrm{THP})_{2}\left(\mathrm{H}_{2} \mathrm{O}\right)_{2}(\mathrm{Cl})_{2}$ was carried out on skin injuries of laboratory mice after it was converted into cream with vaseline and was found to have a very potent influence in healing skin injuries.
\end{abstract}

Keywords: Nanocomplexes; Theophylline; Ultrasonic sonication; Bacterial strains; TEM

\section{Introduction}

Transition metal complexes (TMCs) are an exciting class of compounds that can be used nearly in any branch of chemistry and technology [1, 2]. Through suitable changes of either the core metal atom or the ligand sphere they can be tuned to a specific function. These complexes can be incorporated in chemical or biological matrices and used in a variety of environments [3]. TMCs are essential components of the human body's structural and functional elements and play a vital role in many physiological or pathological procedures [4]. TMCs drugs (TMCD) have become increasingly important in inorganic and medicinal chemistry and have attracted a great deal of attention over the past decade in drug development strategies [4, 5]. The studies have also shown that the nanomaterials and nanocomplexes have distinctive physical, chemical and biological applications [6-17]. Theophylline, 1,3-dimethylxanthine, with significant biological characteristics, is a purine alkaloid. Theophylline (Scheme 1) is used for treating illnesses 
<smiles>Cn1c(=O)c2[nH]cnc2n(C)c1=O</smiles>

Scheme 1 The molecular structure of theophylline.

like asthma and chronic obstructive pulmonary disease in medicine. Theophylline transition metal complexes can serve as model compounds to study the relationship between metal ions and nucleic acid oxo purine bases [18-22]. Theophylline functions as a monodentate ligand in a neutral or fundamental environment and coordinates to metal ions through N7 atom [23-27]. In some instances, it functions as a bidentate $\mathrm{N}(7) / \mathrm{O}(6)$ chelating ligand or as a bridging ligand with $\mathrm{N}(7) / \mathrm{O}(6)$ chelation and $\mathrm{N}(9)$ coordination simultaneously [28, 29]. In this paper, we reported the synthesis and characterization of $\mathrm{Cu}(\mathrm{II}), \mathrm{Ni}(\mathrm{II})$ and $\mathrm{Co}(\mathrm{II})$ nanocomplexes with theophylline as a ligand for biological applications.

\section{Experimental}

\section{Materials and methods}

All Sigma-Aldrich chemicals and solvents were used as obtained. During the experimental steps, deionized water was used.

\section{Synthesis of nano complexes}

3 medical nanocomplexes of the metal ions of $\mathrm{Cu}(\mathrm{II}), \mathrm{Ni}(\mathrm{II})$, and $\mathrm{Co}(\mathrm{II})$ with theophylline (THP) as a ligand were synthesized using ultrasonic sonication method as depicted in Scheme 2. Accordingly, theophylline $(0.004 \mathrm{~mol})$ was dissolved in $30 \mathrm{~mL}$ fresh $\mathrm{NaOH}(0.004 \mathrm{~mol})$ solution to prepare sodium salt of the medical ligand. The obtained solution was heated up to $70{ }^{\circ} \mathrm{C}$, and then metals (II) chlorides (0.002 $\mathrm{mol}$ in $30 \mathrm{~mL}$ ) were added to aqueous solution. The solution mixture was kept under ultrasonic sonication for $3 \mathrm{~h}$ at $70{ }^{\circ} \mathrm{C}$. Subsequently, crystals of good quality emerged at room temperature and overnight incubation. Novel complexes isolated by filtration were then washed and dried well in air.

\section{Characterization}

3 nanoscale complexes were characterized by some devices. Physical properties, size and morphology of nano complexes were measured by transmission electron microscopy (TEM). Determination of melting point, molar conductivity, and solubility were achieved in addition to flame atomic absorption, Fouriertransform infrared spectroscopy (FTIR), and elemental analysis $(\mathrm{C}, \mathrm{H}, \mathrm{N}$, and $\mathrm{S})$ to investigate and suggest the structure of nano complexes.

\section{Antibacterial test}

3 theophylline nanocomplexes were selected to carry out the antibacterial examination. $10^{-3} \mathrm{M}$ solutions were prepared by dissolving the appropriate weights of the selected nanocomplexes in dimethyl sulfoxide (DMSO) in addition to pure theophylline solution of the same concentration. The prepared solutions were then used to examine their antibacterial activity using the agar diffusion method. 4 types of bacterial strains, Staphylococcus aureus, Bacillus subtilis (gram-positive bacteria), Klebsiella pneumoniae and Escherichia Coli (gram-negative bacteria) were chosen for this study. The approximate number of bacteria cells in agar plates was found to be $1.5 \times 10^{8}$ colony-forming units per milliliter by comparing it with the McFarland Standard. A cavity was made in each plate at a diameter<smiles></smiles><smiles>CC(O)Cc1nc2c(c(=O)n(C)c(=O)n2C)n1[NH3+]</smiles><smiles>Cn1c(=O)c2c(ncn2[C@@H](Cl)[C@@H](O)n2cnc3c2c(=O)n(C)c(=O)n3C)n(C)c1=O</smiles>

Scheme 2 Synthesis route to nanocomplexes, $\mathrm{M}$ = Ni(II), CO(II), and $\mathrm{Cu}(\mathrm{II})$. 
of $5 \mathrm{~mm}$ to fill with the solution of medical nano scale of complexes. The plates were incubated for $24 \mathrm{~h}$ at $37^{\circ} \mathrm{C}$. The diameters of the resulting inhibition zones were measured and tabulated. Owing to the highest inhibition zone exhibited by copper nanocomplex $\left[\mathrm{Cu}(\mathrm{THP})_{2}\left(\mathrm{H}_{2} \mathrm{O}\right)_{2}(\mathrm{Cl})_{2}\right]$ against all studied bacterial strains, it was selected for further estimation of its antibacterial activity in vivo.

\section{In vivo estimation of antibacterial activity}

To study the antibacterial effect of $\left[\mathrm{Cu}(\mathrm{THP})_{2}\left(\mathrm{H}_{2} \mathrm{O}\right)_{2}(\mathrm{Cl})_{2}\right]$ complex in nanoscale, a group of mice ( $\mathrm{n}=10,2$ months old) was injured and contaminated with gram-positive bacteria (Staphylococcus aureus). The nanoscale complex
$\left[\mathrm{Cu}(\mathrm{THP})_{2}\left(\mathrm{H}_{2} \mathrm{O}\right)_{2}(\mathrm{Cl})_{2}\right]\left(10^{-3} \mathrm{M}\right)$ was mixed with Vaseline and applied onto the contaminated injures up to 10 days. Another group of mice was treated similarly, except Vaseline was applied without nanoscale complex to act as a control group.

\section{Results and Discussion \\ Fourier-transform infrared spectroscopy (FTIR) spectra}

The FTIR spectrum of theophylline (Fig. 1) showed an absorption band at $\left(3120 \mathrm{~cm}^{-1}\right)$ which referred to $v(\mathrm{NH})$ which disappeared in the FTIR spectra of all nanocomplexes (Figs. 2-4). This indicated that (NH) group was involved in coordination of theophylline

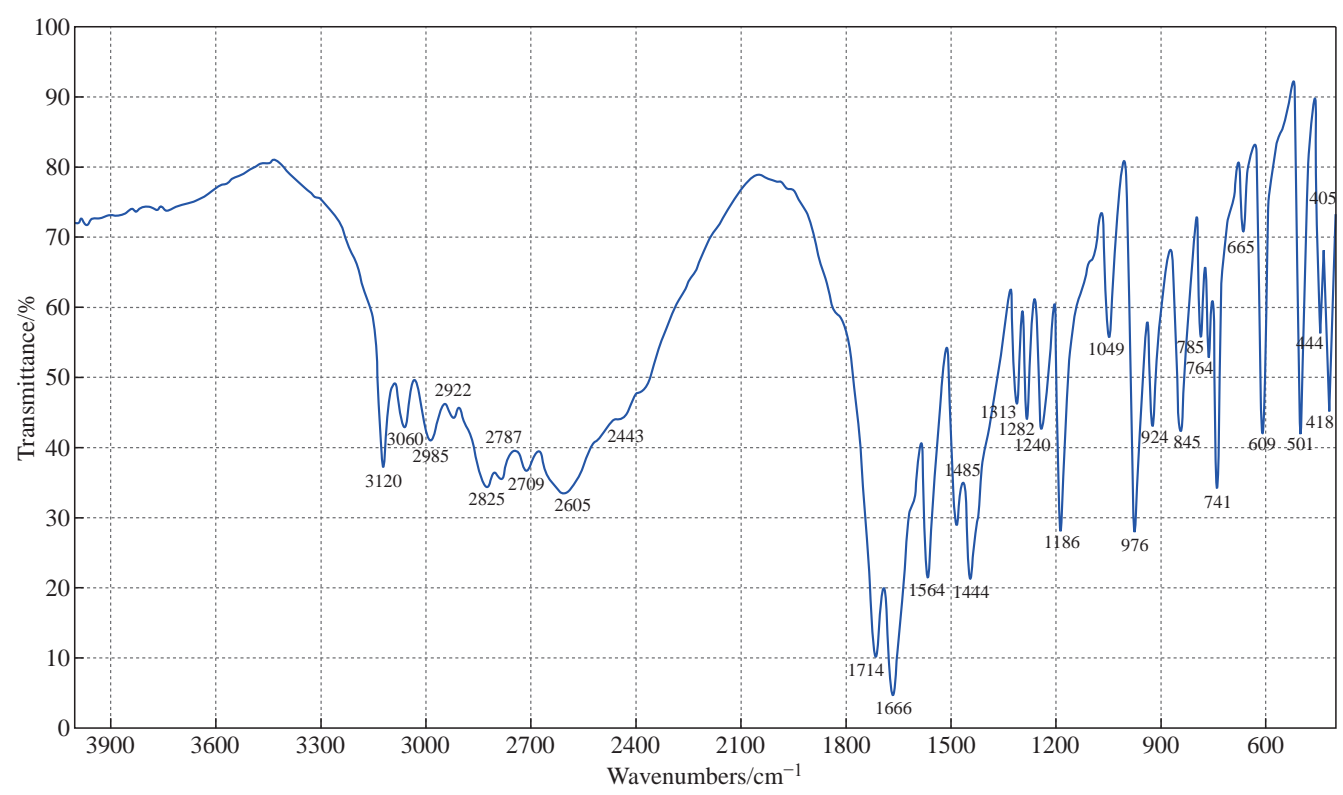

Fig. 1 FTIR spectrum of theophylline (THP).

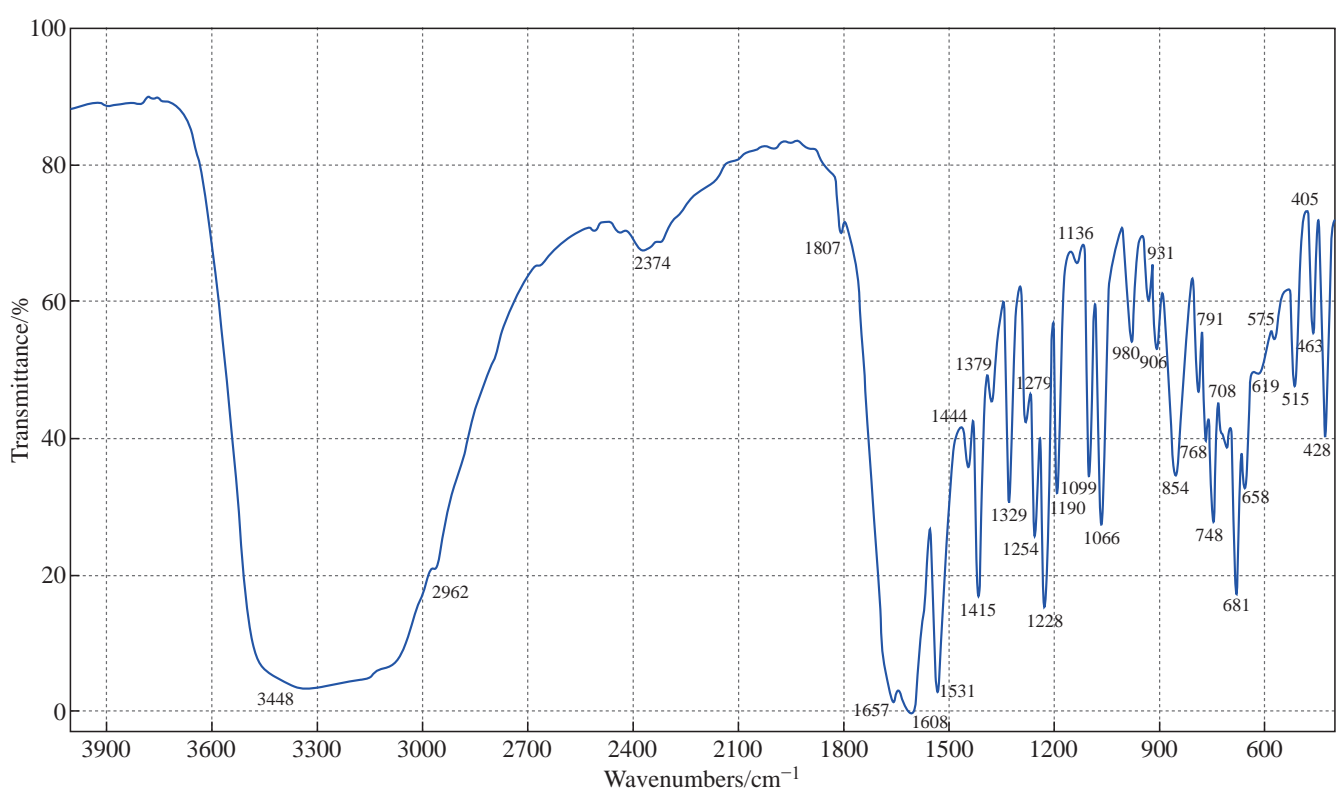

Fig. 2 FTIR spectrum of the $\left[\mathrm{Co}(\mathrm{THP})_{2}\left(\mathrm{H}_{2} \mathrm{O}\right)_{2}(\mathrm{Cl})_{2}\right]$ nanocomplex. 


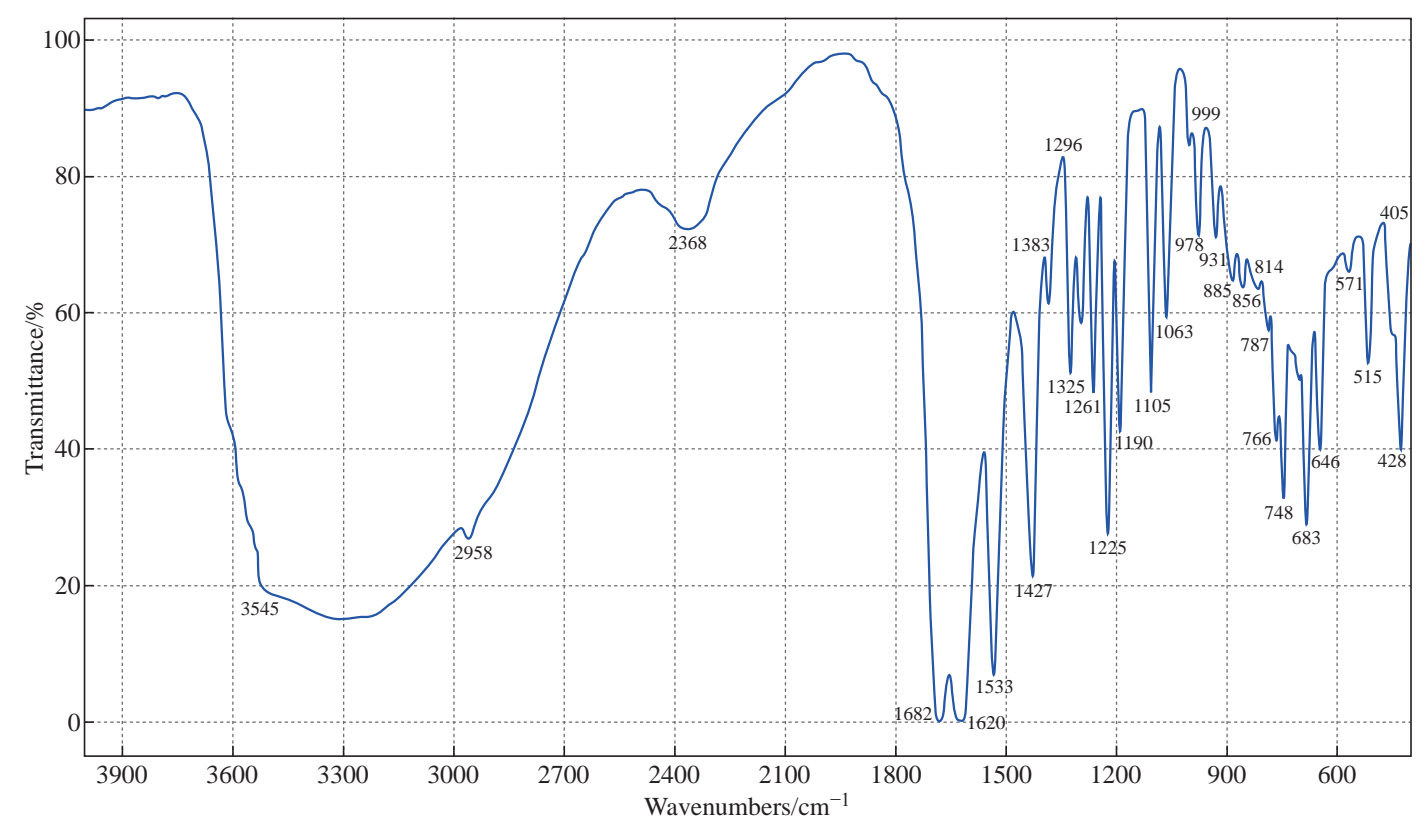

Fig. 3 FTIR spectrum of the $\left[\mathrm{Cu}(\mathrm{THP})_{2}\left(\mathrm{H}_{2} \mathrm{O}\right)_{2}(\mathrm{Cl})_{2}\right]$ nanocomplex.

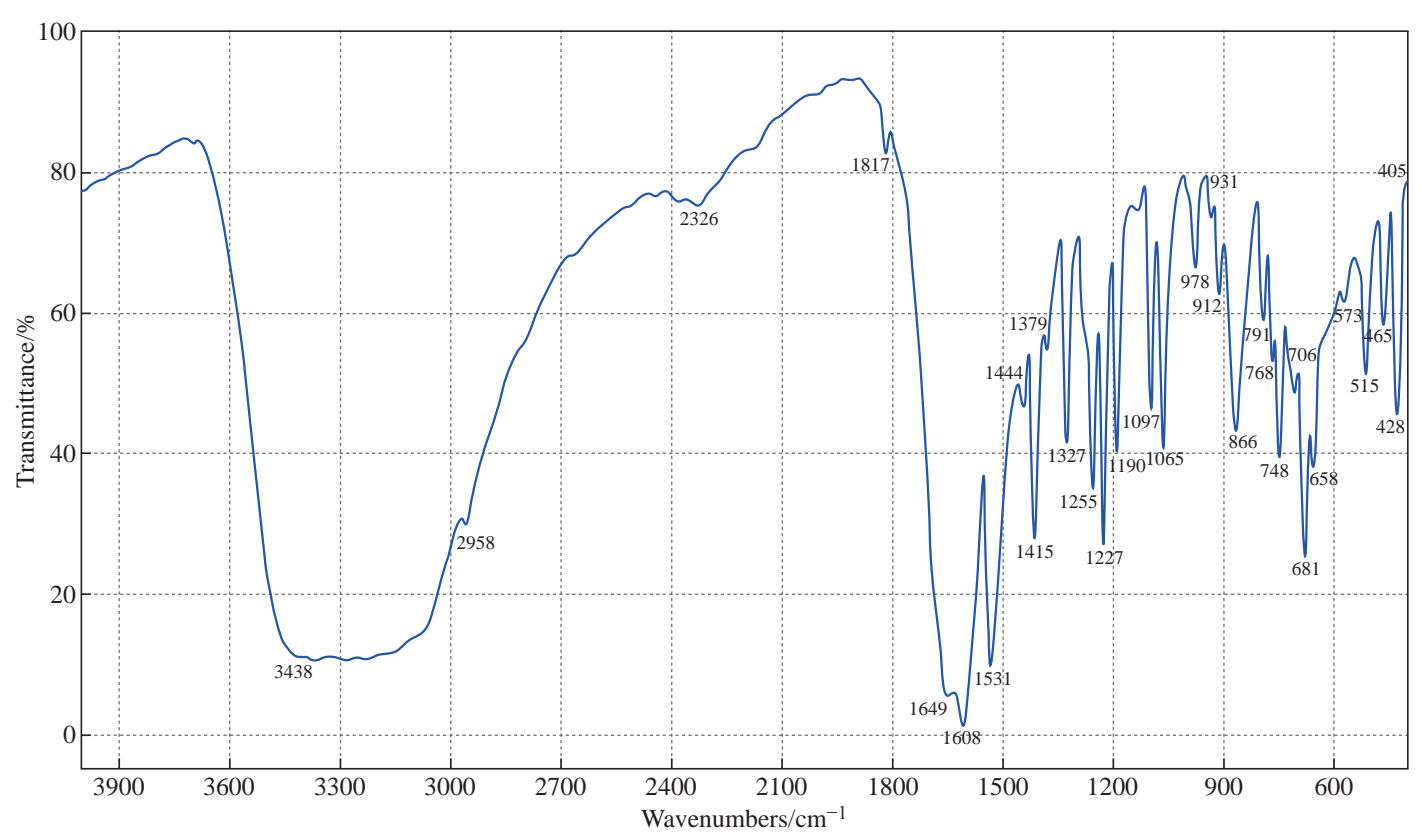

Fig. 4 FTIR spectrum of the $\left[\mathrm{Ni}(\mathrm{THP})_{2}\left(\mathrm{H}_{2} \mathrm{O}\right)_{2}(\mathrm{Cl})_{2}\right]$ nanocomplex.

with the metal ions. An additional broad absorption band could be seen in the region of $3560-3350 \mathrm{~cm}^{-1}$ for all prepared complexes which represented the water stretching vibration, indicating involvement of water molecules in coordination. A new band in all complexes appeared at $569-573 \mathrm{~cm}^{-1}$ which referred to the coordination of metal (N-M). Furthermore, all vibration bands in the nanocomplexes shifted to lower frequency as compared with free theophylline due to hydrogen bonds of water molecules with the carbonyl and amine groups [30].

\section{Physical properties and elemental analysis of synthesized metal nano complexes}

The physical properties and elemental analysis as well as metal content of complexes are described in Table 1, 2 and 3. The elemental analysis (C, H, N, and $\mathrm{S})$ was performed on all synthesized nano complexes to determine their structural molecular formula through convergence of theoretical values with the practical values. The metal ion percentage of the complexes was determined using the atomic absorption methods. Most of these results were in a good agreement with 
Table 1 Elements analysis and atomic absorption spectroscopy for nanocomplexes

\begin{tabular}{|c|c|c|c|c|c|c|}
\hline \multirow{2}{*}{ Nanocomplexes } & \multirow{2}{*}{$\begin{array}{l}\text { Molecular } \\
\text { Formula }\end{array}$} & \multirow{2}{*}{$\begin{array}{c}\text { M.wt } \\
\left(\mathrm{g} \cdot \mathrm{mol}^{-1}\right)\end{array}$} & \multicolumn{4}{|c|}{$\begin{array}{l}\text { Metal analyses (\%) } \\
\text { Found (calc.) }\end{array}$} \\
\hline & & & $\mathrm{C}$ & $\mathrm{H}$ & $\mathrm{N}$ & M \\
\hline$\left[\mathrm{Co}(\mathrm{THP})_{2}\left(\mathrm{H}_{2} \mathrm{O}\right)_{2}(\mathrm{Cl})_{2}\right]$ & $\mathrm{C}_{14} \mathrm{H}_{18} \mathrm{~N}_{8} \mathrm{O}_{6} \mathrm{CoCl}_{2}$ & 523.839 & $\begin{array}{c}32.07 \\
(31.42)\end{array}$ & $\begin{array}{c}3.44 \\
(3.60)\end{array}$ & $\begin{array}{c}21.38 \\
(21.11)\end{array}$ & $\begin{array}{c}11.25 \\
(12.31)\end{array}$ \\
\hline$\left[\mathrm{Cu}(\mathrm{THP})_{2}\left(\mathrm{H}_{2} \mathrm{O}\right)_{2}(\mathrm{Cl})_{2}\right]$ & $\mathrm{C}_{14} \mathrm{H}_{18} \mathrm{~N}_{8} \mathrm{O}_{6} \mathrm{CuCl}_{2}$ & 528.446 & $\begin{array}{c}31.79 \\
(32.06)\end{array}$ & $\begin{array}{c}3.41 \\
(3.23)\end{array}$ & $\begin{array}{c}21.19 \\
(20.51)\end{array}$ & $\begin{array}{c}12.02 \\
(11.23)\end{array}$ \\
\hline$\left[\mathrm{Ni}(\mathrm{THP})_{2}\left(\mathrm{H}_{2} \mathrm{O}\right)_{2}(\mathrm{Cl})_{2}\right]$ & $\mathrm{C}_{14} \mathrm{H}_{18} \mathrm{~N}_{8} \mathrm{O}_{6} \mathrm{NiCl}_{2}$ & 523.616 & $\begin{array}{c}32.08 \\
(31.88)\end{array}$ & $\begin{array}{c}3.44 \\
(3.54)\end{array}$ & $\begin{array}{l}21.39 \\
(21.55)\end{array}$ & $\begin{array}{c}11.21 \\
(10.20)\end{array}$ \\
\hline
\end{tabular}

Table 2 Molar conductance and melting point of prepared nanocomplexes

\begin{tabular}{cccc}
\hline Prepared nanocomplexes & Color & MP $\left({ }^{\circ} \mathrm{C}\right)$ & $\begin{array}{c}\text { Molar cond. } \\
\left(\mathbf{\Omega}^{-1} \cdot \mathrm{cm}^{2} \cdot \mathrm{mol}^{-1}\right)\end{array}$ \\
\hline$\left[\mathrm{Co}(\mathrm{THP})_{2}\left(\mathrm{H}_{2} \mathrm{O}\right)_{2}(\mathrm{Cl})_{2}\right]$ & Pink & $300-298$ & 16.7 \\
{$\left[\mathrm{Cu}(\mathrm{THP})_{2}\left(\mathrm{H}_{2} \mathrm{O}\right)_{2}(\mathrm{Cl})_{2}\right]$} & Greenish blue & $304-302$ & \\
{$\left[\mathrm{Ni}(\mathrm{THP})_{2}\left(\mathrm{H}_{2} \mathrm{O}\right)_{2}(\mathrm{Cl})_{2}\right]$} & Light blue & $310-308$ & 10.5 \\
\hline
\end{tabular}

Table 3 Solubility of theophylline and nanocomplexes

\begin{tabular}{|c|c|c|c|c|c|c|c|}
\hline Nanocomplexes & DMSO & Cold water & $\begin{array}{l}\text { Hot water } \\
\text { (above 40) }\end{array}$ & Acetone & $\mathrm{EtOH}$ & $\mathrm{CHCl}_{3}$ & $\mathrm{MeOH}$ \\
\hline$\left[\mathrm{Co}(\mathrm{THP})_{2}\left(\mathrm{H}_{2} \mathrm{O}\right)_{2}(\mathrm{Cl})_{2}\right]$ & ++ & - & + & + & ++ & - & + \\
\hline$\left[\mathrm{Cu}(\mathrm{THP})_{2}\left(\mathrm{H}_{2} \mathrm{O}\right)_{2}(\mathrm{Cl})_{2}\right]$ & ++ & - & ++ & + & + & - & + \\
\hline$\left[\mathrm{Ni}(\mathrm{THP})_{2}\left(\mathrm{H}_{2} \mathrm{O}\right)_{2}(\mathrm{Cl})_{2}\right]$ & ++ & - & ++ & ++ & ++ & + & ++ \\
\hline Theophylline & ++ & - & ++ & - & ++ & + & ++ \\
\hline
\end{tabular}

Note: ++, high solubility; +, partial solubility; -, insolubility.

the theoretical values. The percentage of metal to ligand was $2: 1$, Octahedral structure was suggested according to the previous measurements whose results are listed in Table 1 and 2.

Additionally, the molar conductance values of ligand and their complexes were measured in DMSO as a solvent at concentration of $10^{-3} \mathrm{M}$. The results showed low values of molar conductivity (16.7 $6.1 \Omega^{-1} \cdot \mathrm{cm}^{-1} \cdot \mathrm{mol}^{-1}$ ), which indicated that all chlorine ions markedly contributed to coordination. Melting points of the ligand and its nanocomplexes were also measured as shown in Table 2.

The solubility of nanocomplexes and theophylline at room temperature was tested using several solvents as summarized in the Table 3.

\section{Transmission electron microscopy (TEM) measurement}

The results of transmission electron microscope (TEM) of the synthesized medical nanocomplexes in different approximation scales are depicted in Fig. 5,
6 and 7. It was clearly shown that all the synthesized samples were free from any aggregation, and the dimensions in all synthesized complexes were within the nanoscale (less than $100 \mathrm{~nm}$ ) which indicated the type of the particles being nanoparticles and the zero dimension which is widely preferred in preparing nanoscale particles. The average size was calculated randomly from the figures as shown in Table 4.

\section{Evaluation of antibacterial activity}

In the present study, the antibacterial effect of nanocomplexes was tested against gram-positive (Staphylococcus aureus and Bacillus subtilis) and gram-negative (Klebsiella pneumonia and Escherichia

Table 4 Average size nanocomplexes investigated by TEM

\begin{tabular}{cc}
\hline $\begin{array}{c}\text { Complexes formula } \\
\text { (nano scales) }\end{array}$ & Ave. particle size $(\mathrm{nm})$ \\
\hline$\left[\mathrm{Ni}(\mathrm{THP})_{2}\left(\mathrm{H}_{2} \mathrm{O}\right)_{2}(\mathrm{Cl})_{2}\right]$ & 15 \\
{$\left[\mathrm{Co}(\mathrm{THP})_{2}\left(\mathrm{H}_{2} \mathrm{O}\right)_{2}(\mathrm{Cl})_{2}\right]$} & 25 \\
{$\left[\mathrm{Cu}(\mathrm{THP})_{2}\left(\mathrm{H}_{2} \mathrm{O}\right)_{2}(\mathrm{Cl})_{2}\right]$} & 20 \\
\hline
\end{tabular}



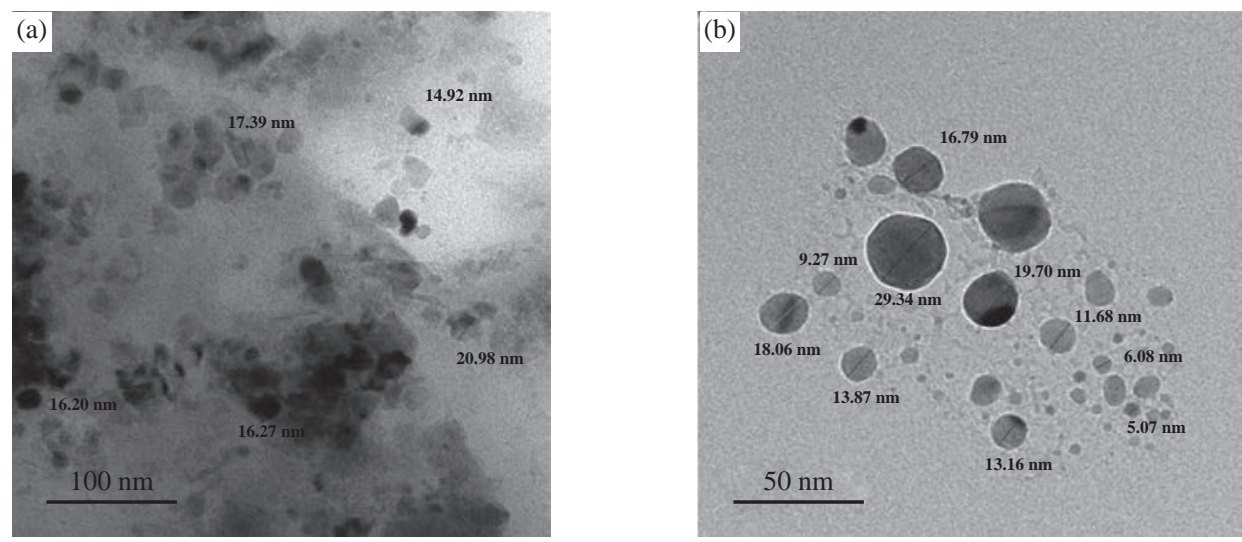

Fig. 5 TEM of $\left[\mathrm{Ni}(\mathrm{THP})_{2}\left(\mathrm{H}_{2} \mathrm{O}\right)_{2}(\mathrm{Cl})_{2}\right]$ nanocomplex, (a) $100 \mathrm{~nm}$ scale, and (b) $50 \mathrm{~nm}$ scale.
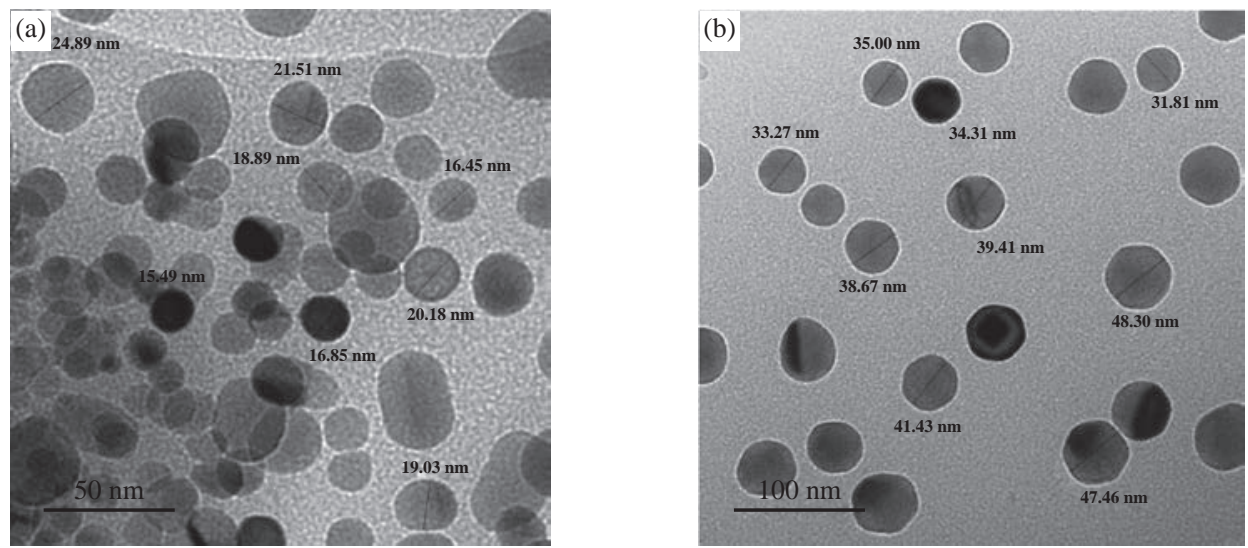

Fig. 6 TEM of $\left[\mathrm{Co}(\mathrm{THP})_{2}\left(\mathrm{H}_{2} \mathrm{O}\right)_{2}(\mathrm{Cl})_{2}\right]$ nanocomplex, (a) $50 \mathrm{~nm}$ scale, and (b) $100 \mathrm{~nm}$ scale.
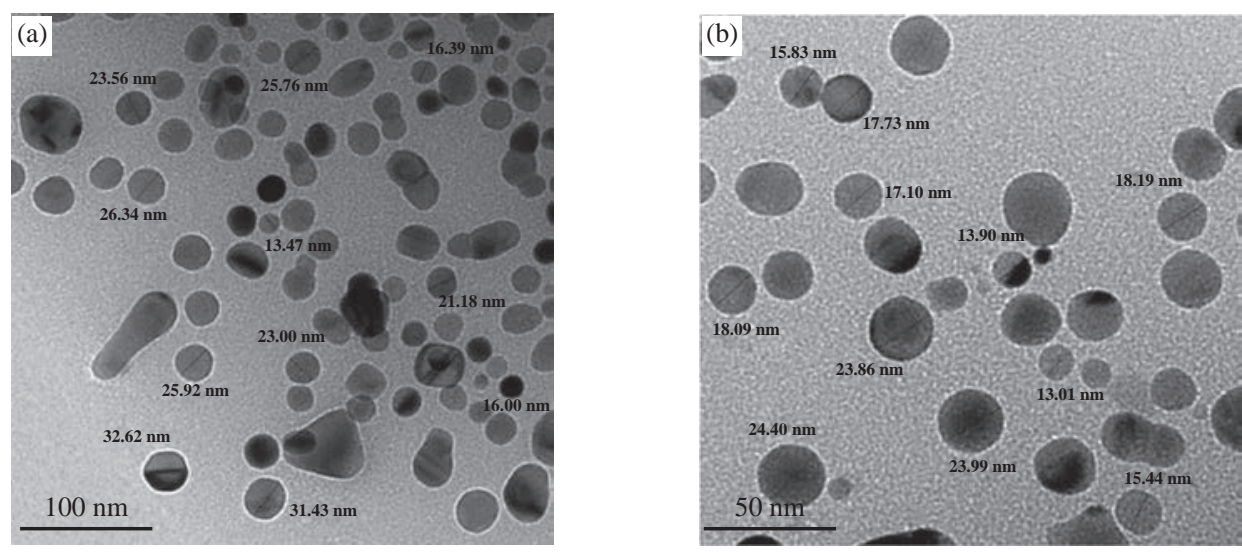

Fig. 7 TEM of $\left[\mathrm{Cu}(\mathrm{THP})_{2}\left(\mathrm{H}_{2} \mathrm{O}\right)_{2}(\mathrm{Cl})_{2}\right]$ nanocomplex, (a) $100 \mathrm{~nm}$ scale, and (b) $50 \mathrm{~nm}$ scale.

coli) bacterial strains. The obtained results indicated that these nanocomplexes exhibited powerful antibacterial activity as those nano complexes were able to inhibit the bacterial growth by inhibition zone reaching 98 - 100\% (Fig. 8 and Table 5). This inhibition is considered unique through disrupting of bacterial cell membrane and inhibiting growth as a result of the dispersal of the external electrical potential of its membrane, due to the high activity and high ability to kill bacteria of nanocomplexes [31]. In view of the results of the examination, it was found that copper nanocomplex $\left[\mathrm{Cu}(\mathrm{THP})_{2}\left(\mathrm{H}_{2} \mathrm{O}\right)_{2}(\mathrm{Cl})_{2}\right]$ gave the highest inhibition zone by $100 \%$ of each type of bacterial strains.

\section{Evaluation of antibacterial activity in vivo}

In this study, 10 white laboratory mice were used, divided into 2 groups (5 mice in each group), and infected with Staphylococcus aureus bacteria by showing signs of inflammation in the region in the form of tissues, dead cells and blood congestion (Fig. 9). The inflammation was treated using an ointment consisting of the nanocomplex $\left[\mathrm{Cu}(\mathrm{THP})_{2}\left(\mathrm{H}_{2} \mathrm{O}\right)_{2}(\mathrm{Cl})_{2}\right]$ 
$\left(10^{-3} \mathrm{M}\right)$ mixed with Vaseline.

The results showed a significant decrease ( $\mathrm{P}<$ 0.01 ) in the lesion area of the skin of the tested mice between the $5^{\text {th }}$ and $10^{\text {th }}$ day of treatment with Vaseline mixed nanocomplex. The results were compared with
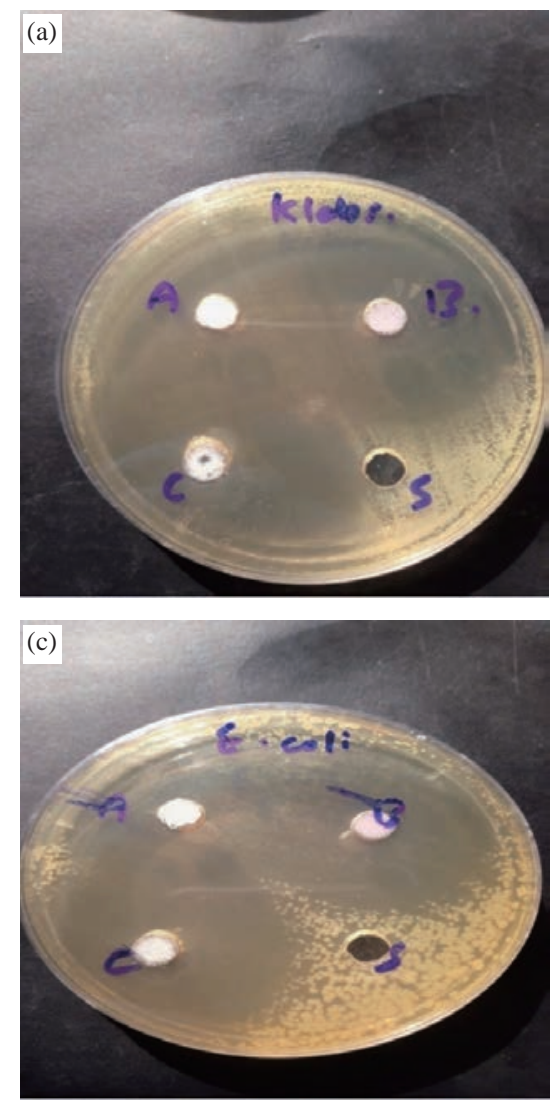

those obtained from treatment with only Vaseline and mice without treatment (Fig. 10). Thus, the treatment with nanocomplex-mixed Vaseline was more effective than treatment with Vaseline only, as illustrated in Table 6 .
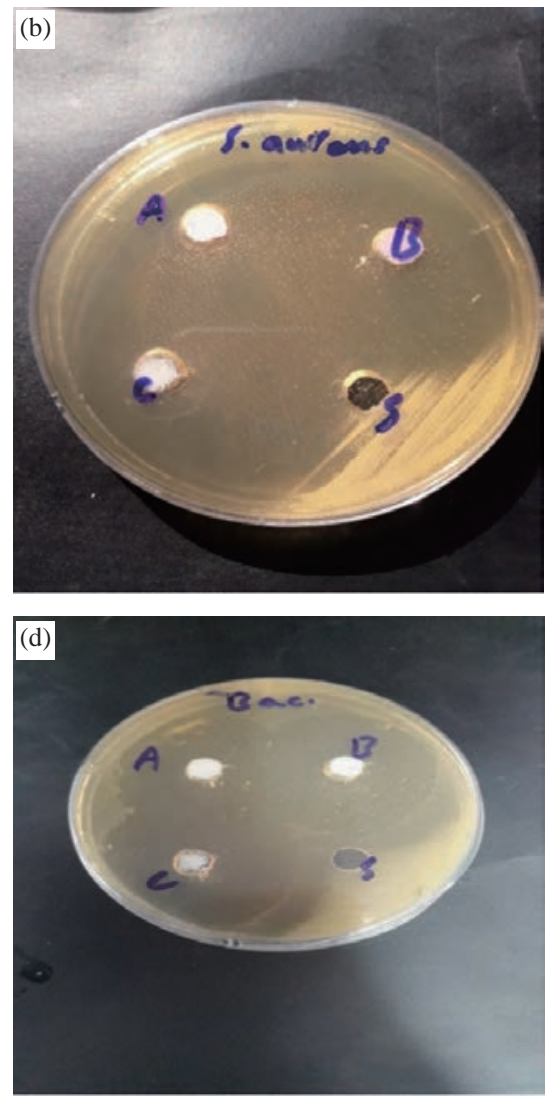

Fig. 8 The activity of nanocomplexes against bacteria: (a) Klebsiella pneumoniae, (b) Staphylococcus aureus, (c) Escherichia coli, and (d) Bacillus subtilis.

Table 5 Effect of nanocomplexes as represented by inhibition zone (mm) against different bacterial species

\begin{tabular}{|c|c|c|c|c|}
\hline Klebsiella pneumoniae & Bacillus subtilis & Escherichia coli & Staphylococcus aureus & Complexes formula \\
\hline$\left[\mathrm{Co}(\mathrm{THP})_{2}\left(\mathrm{H}_{2} \mathrm{O}\right)_{2}(\mathrm{Cl})_{2}\right](\mathrm{A})$ & Out scale & 49 & 42 & 46 \\
\hline$\left[\mathrm{Ni}(\mathrm{THP})_{2}\left(\mathrm{H}_{2} \mathrm{O}\right)_{2}(\mathrm{Cl})_{2}\right] \quad(\mathrm{B})$ & Out scale & 35 & 37 & 42 \\
\hline$\left[\mathrm{Cu}(\mathrm{THP})_{2}\left(\mathrm{H}_{2} \mathrm{O}\right)_{2}(\mathrm{Cl})_{2}\right](\mathrm{C})$ & Out scale & Out scale & 49 & Out scale \\
\hline Theophylline (S) & -- & -- & -- & -- \\
\hline DMSO & -- & -- & -- & -- \\
\hline
\end{tabular}

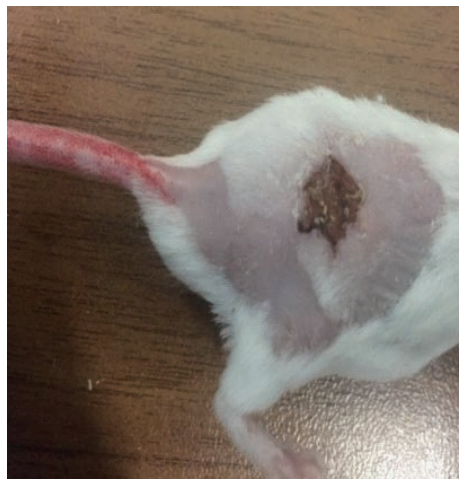

(a) Without treatment

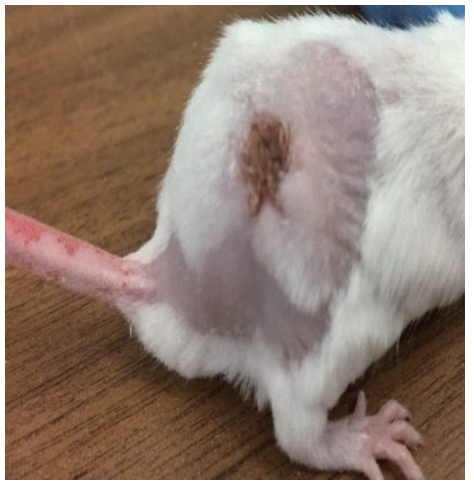

(b) 5 days

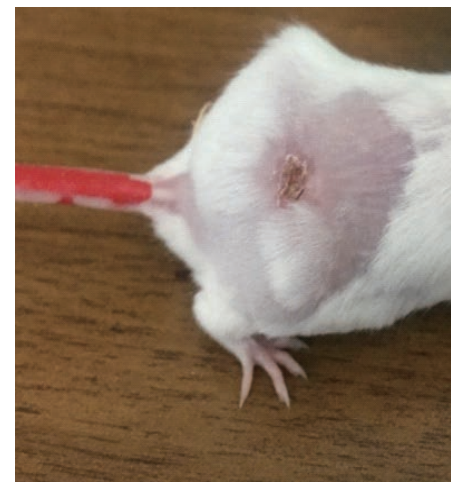

(c) 10 days

Fig. 9 Treatment effect of Vaseline only on the mice without nanocomplex: (a) Without treatment; (b) after 5 days; and (c) after 10 days. 


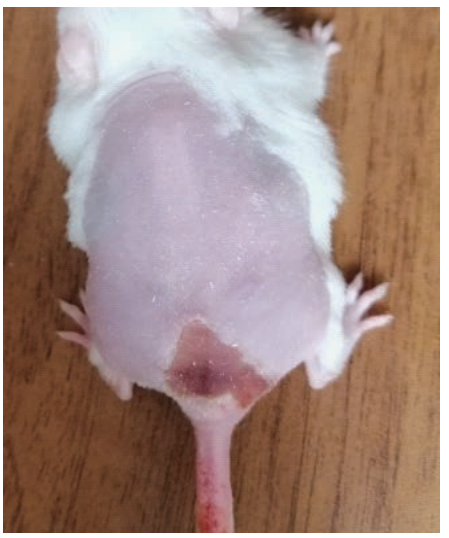

(a) Without treatment

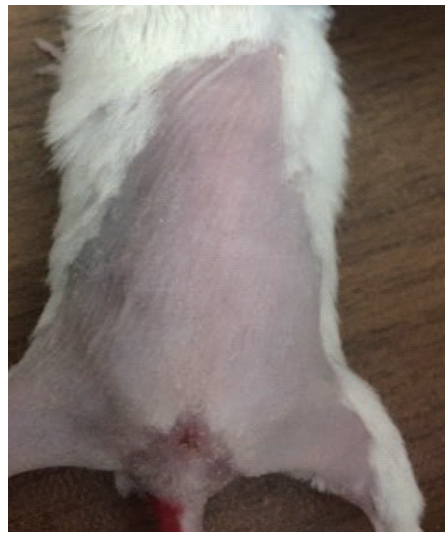

(b) 5 days

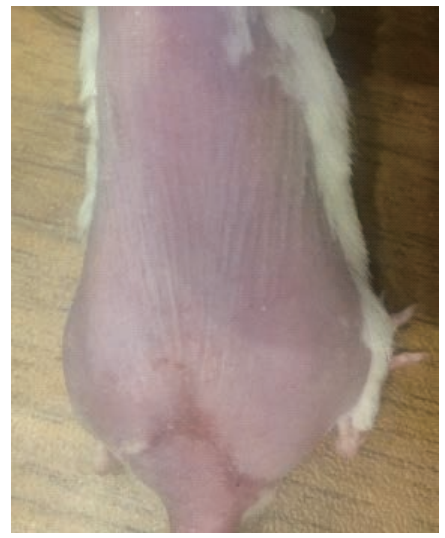

(c) 10 days

Fig. 10 Treatment effect of Vaseline mixed with nanocomplex on the mice: (a) Without treatment; (b) after 5 days; and (c) after 10 days.

Table 6 Infection area $(\mathrm{cm})$ of the skin of mice infected with bacterial infection before and after treatment

\begin{tabular}{ccc}
\hline & Mean \pm SD of total lesion area $(\mathrm{cm})$ & \\
\hline Day of treatment & Treatment with Vaseline only & Treatment with Vaseline mixed with nano complex \\
\hline 0 (without treatment) & $2.24 \pm 0.68$ & $2.31 \pm 0.74$ \\
5 days & $1.89 \pm 0.51$ & $1.21 \pm 0.47$ \\
10 days & $0.68 \pm 0.24$ & $0.11 \pm 0.02$ \\
P value & $\mathrm{P}<0.01$ & $\mathrm{P}<0.01$ \\
& $\mathrm{P}<0.01$, highly significant & \\
\hline
\end{tabular}

\section{Conclutions}

Each method of preparation has advantages and disadvantages with known problems, such as expense, particle size, aggregation etc. Our method has shown that the complexes can be easily synthesized without aggregation. An octahedral structure of nanocomplexes was suggested and proved by melting point, molar conductivity, solubility, flame atomic absorption, FTIR and elemental analysis (C, H, N, and S). The yield was clean and without chemical contamination, which was suitable for biological applications. The average size of nanocomplexes was in the range of 15 - $25 \mathrm{~nm}$ according to TEM measurement. The application of nanocomplexes on different types of bacteria has revealed high inhibitory effect on bacterial growth. The biological activity of copper nanocomplex $\left[\mathrm{Cu}(\mathrm{THP})_{2}\left(\mathrm{H}_{2} \mathrm{O}\right)_{2}(\mathrm{Cl})_{2}\right]$ was further studied on skin injuries of laboratory mice. Results have shown that the complex has a potential impact on skin inflammation as a preparation mixed with Vaseline.

\section{Acknowledgments}

This work was supported by Department of
Chemistry, College of Science, Mustansiriyah University.

\section{Conflict of Interests}

Authors declare no conflict of interest.

\section{References}

[1] S. Mai, F. Plasser, J. Dorn, et al., Quantitative wave function analysis for excited states of transition metal complexes. Coordination Chemistry Reviews, 2018, 361: 74-97.

[2] N.J. Farrer, L. Salassa, and P.J. Sadler, Photoactivated chemotherapy (PACT): the potential of excited-state d-block metals in medicine. Dalton Transactions, 2009, 48: 10690-10701.

[3] C. Daniel, Photochemistry and photophysics of transition metal complexes: Quantum chemistry. Coordination Chemistry Reviews, 2015, 282: 19-32.

[4] M. Litecká, R. Gyepes, Z. Vargová, et al., Toxic metal complexes of macrocyclic cyclen molecule-synthesis, structure and complexing properties. Journal of Coordination Chemistry, 2017, 70(10): 1698-1712.

[5] K. Kumar, S. Murugesan, Synthesis, characterization and anti-bacterial activity of divalent transition metal complexes of hydrazine and trimesic acid. Journal of Saudi Chemical Society, 2018, 22(1): 16-26.

[6] A.M. Rheima, M.A. Mohammed, S.H. Jaber, et al., Synthesis of silver nanoparticles using the UV-irradiation 
technique in an antibacterial application. Journal of Southwest Jiaotong University, 2019, 54(5): 1-11.

[7] M.A. Mohammed, A.M. Rheima, S.H. Jaber, et al., The removal of zinc ions from their aqueous solutions by $\mathrm{Cr}_{2} \mathrm{O}_{3}$ nanoparticles synthesized via the UV-irradiation method. Egyptian Journal of Chemistry, 2020, 63(2): 425431.

[8] A.M. Rheima, M.A. Mohammed, S.H. Jaber, et al., Inhibition effect of silver-calcium nanocomposite on alanine transaminase enzyme activity in human serum of Iraqi patients with chronic liver disease. Drug Invention Today, 2019, 12(11): 2818-2821.

[9] D.H. Hussain, A.M. Rheima, S.H Jaber, et al., Cadmium ions pollution treatments in aqueous solution using electrochemically synthesized gamma aluminum oxide nanoparticles with DFT study. Egyptian Journal of Chemistry, 2020, 63(2): 417-424.

[10] A.A. Ali, R.M. Al-Hassani, D.H. Hussain, et al., Fabrication of solar cells using novel micro-and nanocomplexes of triazole Schiff base derivatives. Journal of Southwest Jiaotong University, 2019, 54(6): 1-19.

[11] A.M. Rheima, D.H. Hussain, land M.M.A. Almijbilee, Graphene-silver nanocomposite: synthesis, and adsorption study of cibacron blue dye from their aqueous solution. Journal of Southwest Jiaotong University, 2019, 54(6): $1-8$.

[12] D.H. Hussain, H.I. Abdulah, and A.M. Rheima, Synthesis and characterization of $\gamma-\mathrm{Fe}_{2} \mathrm{O}_{3}$ nanoparticles photo anode by novel method for dye sensitized solar cell. International Journal of Scientific and Research Publications, 2016, 6(10): 26-31.

[13] S.H. Jaber, D.H. Hussain, A.M. Rheima, et al., Comparing study of $\mathrm{CuO}$ synthesized by biological and electrochemical methods for biological activity. AlMustansiriyah Journal of Science, 2019, 30(1): 94-98.

[14] A.H. Ismail, H.K. AL-Bairmani, Z.S. Abbas, et al. Synthesis, characterization, spectroscopic, and biological activity studies of Nano scale Zn(II), Mn(II) and Fe(II) theophylline complexes. Journal of Xi'an University of Architecture \& Technology, 2020, 12(2): 2775-2789.

[15] A.M. Rheima, D.H. Hussain, and H.I. Abdulah, Silver nanoparticles: Synthesis, characterization and their used a counter electrodes in novel dye sensitizer solar cell. IOSR Journal of Applied Chemistry, 2016, 9(10): 6-9.

[16] A.A. Ali, R.M. Al-Hassani, D.H. Hussain, et al., Synthesis, spectroscopic, characterization, pharmacological evaluation, and cytotoxicity assays of novel nano and micro scale of copper (II) complexes against human breast cancer cells. Drug Invention Today, 2020, 14(1): 31-39.

[17] Y. Chen, J. Xue, Wusigale, et al., Carboxymethylation of phytoglycogen and its interactions with caseinate for the preparation of nanocomplex. Food Hydrocolloids, 2020, 100: 105390.

[18] D. Nayak, S. Pradhan, S. Ashe, et al., Biologically synthesised silver nanoparticles from three diverse family of plant extracts and their anticancer activity against epidermoid A431 carcinoma. Journal of Colloid and Interface Science, 2015, 457: 329-338.

[19] Z.R. Ranjbar, M. Khatamifar, and S.J. Fatemi, Chelation therapy: Assessing the impact of deferasirox size on lead (II) release from biological systems. Main Group Chemistry, 2018, 17(2): 181-189.

[20] L.M. Novena, S.S. Kumar, S. Athimoolam, et al., Single crystal, vibrational and computational studies of
Theophylline (a bronchodilator drug) and its chloride salt. Journal of Molecular Structure, 2017, 1133: 294-306.

[21] T.J. Kistenmacher, D.J. Szalda, and L.G. Marzilli, Intercalative stacking interactions and interligand hydrogen bonding in metal purine complexes. Crystal and molecular structure of (N-salicylidene-N' methylethylenediamine) (theophyllinato) copper (II) monohydrate. Inorganic Chemistry, 1975, 14(7): 16861691.

[22] N.S. Begum, H. Manohar, Synthesis and X-ray crystal structure of a CuII-theophylline complex: $\left[\mathrm{Cu}(\text { theo })_{2}\left(\mathrm{H}_{2} \mathrm{O}\right)_{3}\right] \cdot 2 \mathrm{H}_{2} \mathrm{O}$. Polyhedron, 1994, 13(2): $307-$ 312.

[23] E. Forizs, A. Debreczeni, A. Patrut, et al., Synthesis, structure and DFT calculations on complexes of palladium (II) with theophylline. Rev Roum Chim, 2010, 55(10): 697-704.

[24] P. Bombicz, J. Madarász, E. Forizs, et al., Structure and thermal behaviour of (SPY-5-12)-(2-aminoethanol-N) (2-aminoethanol-N, O)-bis (theophyllinato) copper (II) dihydrate: A model for DNA-metal interactions. Polyhedron, 1997, 16(20): 3601-3607.

[25] E. Forizs, L. David, O. Cozar, et al., IR and ESR studies on novel $\mathrm{Cu}(\mathrm{II})$ theophyllinato complexes containing mono-or bidentate ligands. Journal of Molecular Structure, 1999, 482: 143-147.

[26] H. El Hamdani, M. El Amane, and C. Duhayon, Crystal structure of tetraaquabis (1, 3-dimethyl-2, 6-dioxo-7Hpurin-7-ido-kN7) cobalt (II). Acta Crystallographica Section E: Crystallographic Communications, 2017, 73(9): 1302-1304.

[27] B. Mihály, E. Forizs, A.Z. Kun, et al., (Diethylenetriamine) bis (theophyllinato) zinc (II) dihydrate. Acta Crystallographica Section E: Structure Reports Online, 2009, 65(5): 579-579.

[28] D.J. Szalda, T.J. Kistenmacher, and L.G. Marzilli, Observation of a direct interaction between the carbonyl oxygen, O (6), of a N (7)-bonded 6-oxopurine and a metal center. Preparation and crystal and molecular structure of (N-3, 4-benzosalicylidene-N', N'dimethylethylenediamine)(theophyllinato) copper (II) monohydrate. Journal of the American Chemical Society, 1976, 98(26): 8371-8377.

[29] J. Lorberth, W. Massa, M.E. Essawi, et al., Trimethylplatinum - theophylline hexamer: A novel Pt6 heterocycle containing both Pt-N and Pt-O bonds. Angewandte Chemie International Edition in English, 1988, 27(9): 1160-1161.

[30] M. Gacki, K. Kafarska, A. Pietrzak, et al., Synthesis, characterisation, crystal structure and biological activity of metal (II) complexes with theophylline. Journal of Saudi Chemical Society, 2019, 23(3): 346-354.

[31] S. Soltani, K. Akhbari, and J. White, Synthesis, crystal structure and antibacterial activity of a homonuclear nickel (II) metal-organic nano supramolecular architecture. Polyhedron, 2020, 176: 114301.

Copyright $\subseteq$ Ahmad Hussein Ismail, Hassanain Kamil AlBairmani, Zainab Sabri Abbas, and Ahmed Mahdi Rheima. This is an open-access article distributed under the terms of the Creative Commons Attribution License, which permits unrestricted use, distribution, and reproduction in any medium, provided the original author and source are credited. 